\title{
Genetic and phenotypic determinants of flavonoid absorption and metabolism: the $\mathrm{COB}$ study
}

\author{
Sumanto Haldar", Noemí T Hernandez, Luisa Ostertag, Peter Curtis, Aedín Cassidy, Anne Marie Minihane \\ From Genes and nutrition, is personalised nutrition the next realistic step? \\ Brussels, Belgium. 25 April 2014
}

\section{Background}

Flavonoids are present in numerous plant foods, including fruits, vegetables, teas, red wine, cocoa, herbs, and spices. Epidemiological data, along with evidence from cell, animal, and limited human intervention trial studies suggest that flavonoids can improve cardiovascular health and reduce the risk of other ageing-related diseases [1-6]. However, the absorption and metabolism of flavonoids, their metabolite profile, and their associated health benefits are highly heterogeneous [7], with the aetiological basis of this variability currently unknown. Our recent stable isotope study, which fed an oral bolus dose of $500 \mathrm{mg}{ }^{13} \mathrm{C}$-labeled cyanidin-3-glucoside to healthy men showed a wide inter-individual variability in anthocyanin metabolism [7].

\section{Methods}

The COB (Chocolate, Orange and Blackberry) study is examining the influence of genotype, age, gender and composition of the intestinal microbiota on the absorption, metabolism and elimination (AME) of flavonoids. It is an acute feeding study with mixed-flavonoids (containing flavan-3-ols, flavanones and anthocyanins) conducted in 120 men and 120 women (Caucasians, of European Origin), from two different age groups, 18-30 $\mathrm{y}$ and 65-77 y. The parent flavonoids and their metabolites will be measured in plasma and urine for up to 48 hours post-feeding. Participants' genotypes will be established using exome sequencing and targeted genotyping for Single Nucleotide Popymorphisms (SNPs) in genes associated with i) pathways involved in flavonoid meta- bolism (in particular phase 1 and 2 enzymes); ii) genes that may alter the intestinal microbial composition; and iii) those modulating gut physiology. The composition of the gut microflora will be analysed by pyrosequencing of $16 \mathrm{~S}$ rRNA and metagenomic technologies.

\section{Results}

The COB intervention is currently ongoing and due for completion in October 2014. 142 tagging SNPs have been identified in candidate genes involved in flavonoid absorption, metabolism and elimination including LPHs (deglycosylation), UGTs (glucuronidation), SULTs (sulfation), COMT (methylation) and $\mathrm{ABC}$ transporters (such as MRP2) which will be analysed in our study population. In order to generate pilot data to help inform the genotyping approach in the $\mathrm{COB}$ study, the impact of a selection of these SNPs (Table 1) on flavonoid metabolism and clinical endpoints is being determined in a completed one year trial involving 47 postmenopausal women [1].

\section{Implications}

The proposed work will advance current knowledge regarding the genetic and physiological determinants of flavonoid absorption and metabolism. Such information would allow greater refinement of current recommended intakes of flavonoid rich foods, such as fruits and vegetables

\section{Trial registration}

ClinicalTrials.gov identifier: NCT01922869, ISRCT N14271372

\footnotetext{
* Correspondence: s.haldar@uea.ac.uk

Department of Nutrition, Norwich Medical School, University of East Anglia, Norwich, NR4 7TJ, UK
} 
Table 1

\begin{tabular}{lllllll}
\hline SNP (Gene) & Variant 1 & number (\%) & Variant 2 & number (\%) & Variant 3 & number (\%) \\
\hline rs4988235 (LPH) & AA & $19(40 \%)$ & AG & $21(45 \%)$ & GG & $6(13 \%)$ \\
rs3760091 (SULT) & CC & $10(21 \%)$ & GC & $19(40 \%)$ & GG & $18(38 \%)$ \\
rs4788068 (SULT) & AA & $8(17 \%)$ & GA & $21(45 \%)$ & GG & $18(38 \%)$ \\
rs2273697 (MRP2) & AA & $5(11 \%)$ & AG & $20(43 \%)$ & GG & $22(47 \%)$ \\
rs737865 (COMT) & AA & $25(53 \%)$ & AG & $21(45 \%)$ & GG & $1(2 \%)$ \\
rs4680 (COMT) & AA & $13(28 \%)$ & AG & $23(49 \%)$ & GG & $11(23 \%)$ \\
\hline
\end{tabular}

Published: 6 June 2014

\section{References}

1. Curtis PJ, Potter J, Kroon PA, Wilson P, Dhatariya K, Sampson M, Cassidy A: Vascular function and atherosclerosis progression after 1 y of flavonoid intake in statin-treated postmenopausal women with type 2 diabetes: a double-blind randomized controlled trial. Am J Clin Nutr 2013, 97:936-942.

2. Cassidy A, Mukamal KJ, Liu L, Franz M, Eliassen AH, Rimm EB: High anthocyanin intake is associated with a reduced risk of myocardial infarction in young and middle-aged women. Circulation 2013, 127:188-196

3. Cassidy A, Rimm EB, O'Reilly EJ, Logroscino G, Kay C, Chiuve SE, Rexrode KM: Dietary flavonoids and risk of stroke in women. Stroke 2012, 43:946-951.

4. Jennings A, Welch AA, Fairweather-Tait SJ, Kay C, Minihane AM, Chowienczyk P, Jiang B, Cecelja M, Spector T, Macgregor A, et al: Highe anthocyanin intake is associated with lower arterial stiffness and central blood pressure in women. Am J Clin Nutr 2012, 96:781-788.

5. Peterson JJ, Dwyer JT, Jacques PF, McCullough ML: Associations between flavonoids and cardiovascular disease incidence or mortality in European and US populations. Nutr Rev 2012, 70:491-508.

6. Hooper L, Kroon PA, Rimm EB, Cohn JS, Harvey I, Le Cornu KA, Ryder JJ, Hall WL, Cassidy A: Flavonoids, flavonoid-rich foods, and cardiovascular risk: a meta-analysis of randomized controlled trials. Am J Clin Nutr 2008, 88:38-50.

7. Czank C, Cassidy A, Zhang Q, Morrison DJ, Preston T, Kroon PA, Botting NP, Kay CD: Human metabolism and elimination of the anthocyanin, cyanidin-3-glucoside: a (13)C-tracer study. Am J Clin Nutr 2013, 97:995-1003.

doi:10.1186/2049-3258-72-S1-O3

Cite this article as: Haldar et al.: Genetic and phenotypic determinants of flavonoid absorption and metabolism: the COB study. Archives of Public Health 2014 72(Suppl 1):03.

\section{Submit your next manuscript to BioMed Central and take full advantage of:}

- Convenient online submission

- Thorough peer review

- No space constraints or color figure charges

- Immediate publication on acceptance

- Inclusion in PubMed, CAS, Scopus and Google Scholar

- Research which is freely available for redistribution

Submit your manuscript at www.biomedcentral.com/submit
Biomed Central 